\title{
COMPARISON OF NUMERICAL ANALYSES WITH A STATIC LOAD TEST OF A CONTINUOUS FLIGHT AUGER PILE
}

\author{
Michal HOLKO ${ }^{1 *}$, Jakub STACHO ${ }^{2}$
}

\section{Abstract}

The article deals with numerical analyses of a Continuous Flight Auger (CFA) pile. The analyses include a comparison of calculated and measured load-settlement curves as well as a comparison of the load distribution over a pile's length. The numerical analyses were executed using two types of software, i.e., Ansys and Plaxis, which are based on FEM calculations. Both types of software are different from each other in the way they create numerical models, model the interface between the pile and soil, and use constitutive material models. The analyses have been prepared in the form of a parametric study, where the method of modelling the interface and the material models of the soil are compared and analysed.

Our analyses show that both types of software permit the modelling of pile foundations. The Plaxis software uses advanced material models as well as the modelling of the impact of groundwater or overconsolidation. The load-settlement curve calculated using Plaxis is equal to the results of a static load test with a more than $95 \%$ degree of accuracy. In comparison, the load-settlement curve calculated using Ansys allows for the obtaining of only an approximate estimate, but the software allows for the common modelling of large structure systems together with a foundation system.
Address

1 Department of Structural Mechanics, Faculty of Civil Engineering, Slovak University of Technology in Bratislava, Slovakia

2 Department of Geotechnics, Faculty of Civil Engineering, Slovak University of Technology in Bratislava, Slovakia

Corresponding author: michal.holko@stuba.sk

\section{Key words}

- Pile foundations,

- replacement piles,

- CFA piles,

- numerical analysis,

- pile design,

- static load test of pile.

\section{INTRODUCTION}

Piles are the most frequently used elements of deep foundations; they transfer a load from an upper structure to a suitable bearing stratum, when the soil mass immediately below a construction is unsuitable. Piles are very often used to reduce the settlement of a superstructure, due to the stringent requirements of the limit deformations of modern projects. Examples of these constructions are new administrative centres, which consist of a complex of high-rise and low-rise buildings. Significantly different buildings cause different contact stresses and settlements. Piles in such cases should be placed under high-rise buildings to achieve an appropriate settlement.

There are more than 100 types of pile foundations used all over the world at present. The most appropriate way of dividing piles according to their technology is: large displacement, small displacement and replacement (non-displacement) (Fleming et al., 2008; Masopust, 1994). New pile technologies are constantly being developed and modified (e.g., Drilled Displacement System (DDS) piles, Continuous Flight Auger (CFA) piles). The advantages and disadvantages of each pile technology according to the requirements of structures and geological conditions were presented by Tomlinson, 


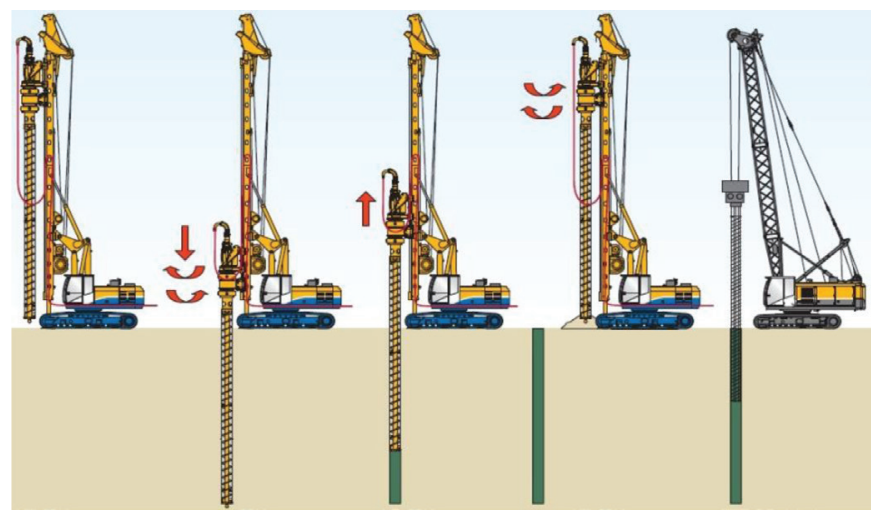

Fig. 1 Process of installation of CFA pile (www.bauerpileco.com/ec) bauer drilling methods).

Woodward (2007) and Brown (2005).

Pile-bearing capacity and settlement are significantly affected by technology. In the past, several calculation methods for determining ultimate resistance and load-settlement curves have been developed.

The analytical methods take into account the impact of technology using empirical coefficients: the coefficient of lateral earth pressure and coefficient of adhesion, see, for example, Brown (2005), Viggiani et al. (2012), Stacho (2013). The options for pile designs using an analytical method for calculating load-settlement curves are transfer curves (Coyle, Reese, 1966) or simplified nonlinear methods (e.g., Masopust, 1994; Wang et al., 2012). Methods for pile design which are based on in-situ tests, e.g., CPT and SPT, have been published by, e.g., Nejad et al. (2009) and NeSmith (2002).

Numerical modelling allows for the obtaining of a deeper understanding of the behaviour of a pile-soil system (e.g., Feda, 1977; Wehnert, Vermeer, 2004; Wakai et al., 1999; Mohamedzein et al., 1999). Numerical modelling often does not take into account the technolical process, and piles are often modelled as "wished-in-place". The modelling of a pile installation using existing empirical coefficients was analysed by Said et al. (2009). Software is constantly being developed which allows for the use of more sophisticated constitutive material models, e.g., the Hardening Soil (HS) model, Hardening Small Strain (HSs) model or hypoplastic models, which better represent the actual behaviour of soils. Other numerical methods, such as the boundary element method (BEM), can also obtain reliable results, but the programs required are complicated and still not convenient enough for practical engineering (Almeida, De Paiva, 2007).

The article deals with piles made by the Continuous Flight Auger (CFA) technology. The impact of the technology has been analysed by (Mandolini et al., 2002; Gavin et al., 2009; Cummins, 2007). The advantages and disadvantages of CFA piles were well described by Brown (2005).

CFA piles are installed by means of an auger with a hollow stem in the middle. The stem is provided with a temporary plate at the bottom during the drilling phase. After drilling to the desired depth, the concrete is pumped under pressure through the hollow stem. During the concreting phase, the auger is lifted and removes soil within the screw. The concreting of the piles must run continuously. The sides of the borehole are thus supported at all times by the soil in the screw or by the concrete. The reinforcement is inserted after the pile's full length is concreted. The ratio between the rate of penetration and the rate of the revolutions of the auger is generally less than the pitch of the screw, thereby reducing the negative impact on the surrounding soil (Masopust, 1994). At present, CFA piles of a diameter of $1.4 \mathrm{~m}$ and a length of $34 \mathrm{~m}$ are possible to install in suitable geological conditions (www.soilmec.it/CFA). The process of the installation of a CFA pile is shown in Fig. 1.

\section{EXECUTION OF THE STATIC LOAD TEST OF A CFA PILE}

A static load test on the analysed CFA pile was performed in January 2007. The tested pile is $15.0 \mathrm{~m}$ long with a diameter of 630 $\mathrm{mm}$. The settlement of the pile head, the uplift of the reaction piles, and the distribution of the load over the pile length using straingauges were recorded. The loading step was $300 \mathrm{kN}$. The static load test was prepared up to the maximal load of $2700 \mathrm{kN}$, including unloading after $1800 \mathrm{kN}$ and $2700 \mathrm{kN}$. Strain-gauges were installed in four layers (see Fig. 2), and used to measure the ratio of the pile base resistance and the pile shaft resistance of the total pile resistance as well as the distribution of the load over the pile.

\section{GEOLOGICAL CONDITIONS OF THE TESTED AREA}

The analysed CFA pile is one element of a piled raft foundation of the high-rise building of the Lakeside Park administrative centre in Bratislava. The building has 22 floors and 3 underground floors. The piled raft foundation consists of a base plate, which is located $6.3 \mathrm{~m}$ below the original surface and is supported by a system of 180 piles.

The geological conditions of the tested area are shown in Fig. 2. The upper layer of a thickness of $2.5 \mathrm{~m}$ consists of well-graded quaternary gravel $(\mathrm{GW})$ and is marked $G$. A stable groundwater level was expected at $0.5 \mathrm{~m}$ below the surface. Fine-grained neogene soils are situated below the quaternary gravel. These soils especially consist of sandy silts (MS) and silts with low plasticity (ML). The homogenized layer is marked as $F_{l}$. A thin layer of silty sands (SM) of a thickness of $1.4 \mathrm{~m}$ is located 12.5 $\mathrm{m}$ below the surface. This layer is especially significant because it has pressurized groundwater. The pore pressure is $120 \mathrm{kPa}$ in this layer. Silts with low-to-medium plasticity (ML-MI) are located below the sandy layer. The homogenized layer is marked as $F_{2}$. Due to the very small pore pressure estimated in this layer, it was not taken into account

Geological investigations of the tested area, which include the descriptive characteristics, grain-size curves, Atterberg's limits and oedometric modulus, were executed by Pokorný, Šujan (2004). The method that was used for the original pile design is based only on these parameters (Masopust, 1994). The shear strength parameters measured on 11 samples and deformation parameters measured on 39 samples were used from a detailed engineering geological investigation (Husár, 2008).

\section{NUMERICAL SIMULATION OF THE PILE FOUNDATION}

As stated above, numerical modelling often does not take into account the effect of a pile installation. However, the effect of a pile installation has a significant influence on the pile's resistance. Some possibilities for the numerical modelling of pile installations have been published by, e.g., Sheng et al., 2005; Kim, Jeong, 2011; Dijkstra et al., 2011; Pucker, Grabe, 2012.

The mechanical behaviour of soils can be modelled with various degrees of accuracy. Due to this fact, selecting an appropriate constitutive model has a significant influence on the accuracy of the solutions. In general, the Linear Elastic (LE) material model, which is based on Hooke's law of isotropic elasticity, is not suitable for modeling soil. This model is appropriate for structural elements, bedrock layers and, in some cases, when a small load causes only elastic deformations. New material models for the modelling of soil are still being developed. Examples of advanced material models are the Hardening Soil (HS) model, Hardening Small strain (HSs) model, and hypoplastic models. 


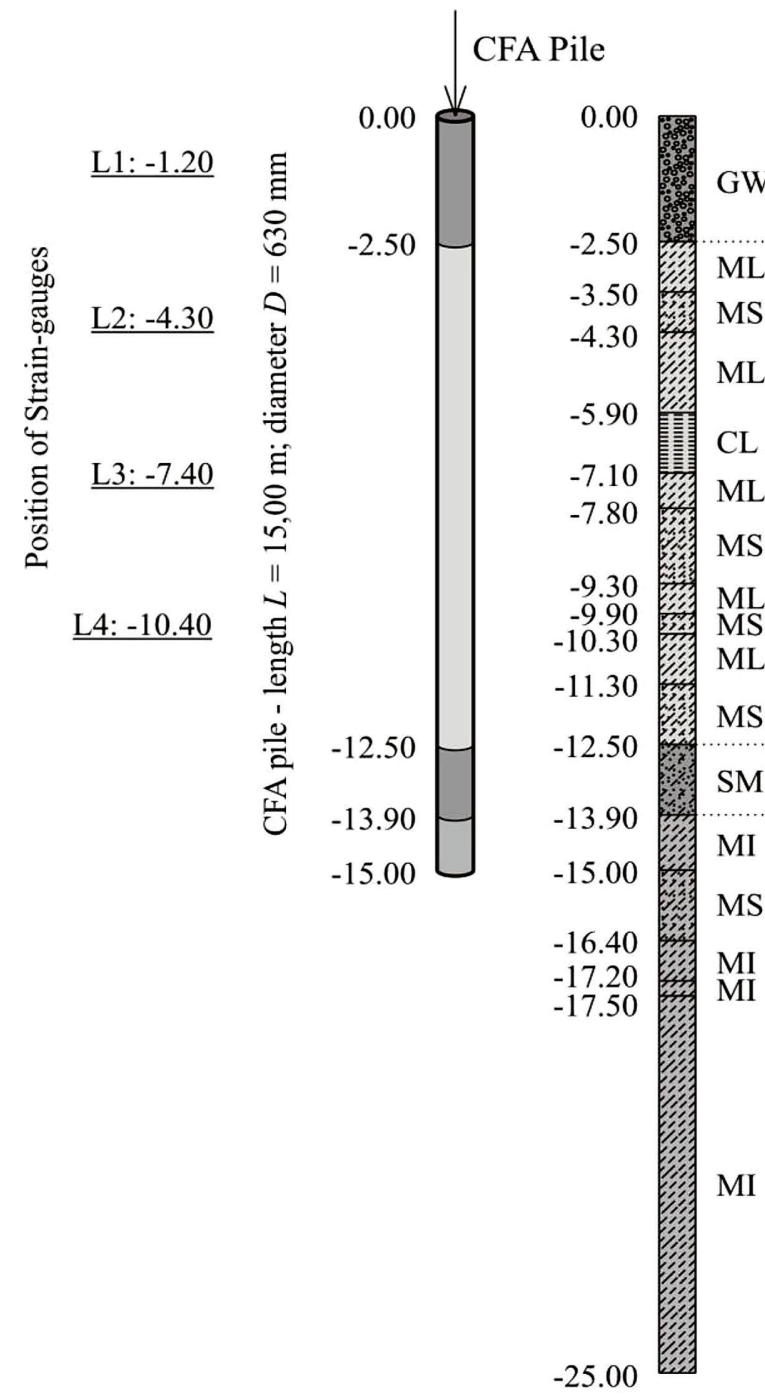

Fig. 2 Geotechnical model of analysed CFA pile.

\subsection{Numerical model of the analysed CFA pile}

The definition of a common geotechnical model was required due to some differences in the use of the Plaxis (2D - axisymmetric) and Ansys (3D) types of software, especially in the creation of a numerical model, the use of constitutive models, and the modelling of pile-soil interactions. A common geotechnical model for both types

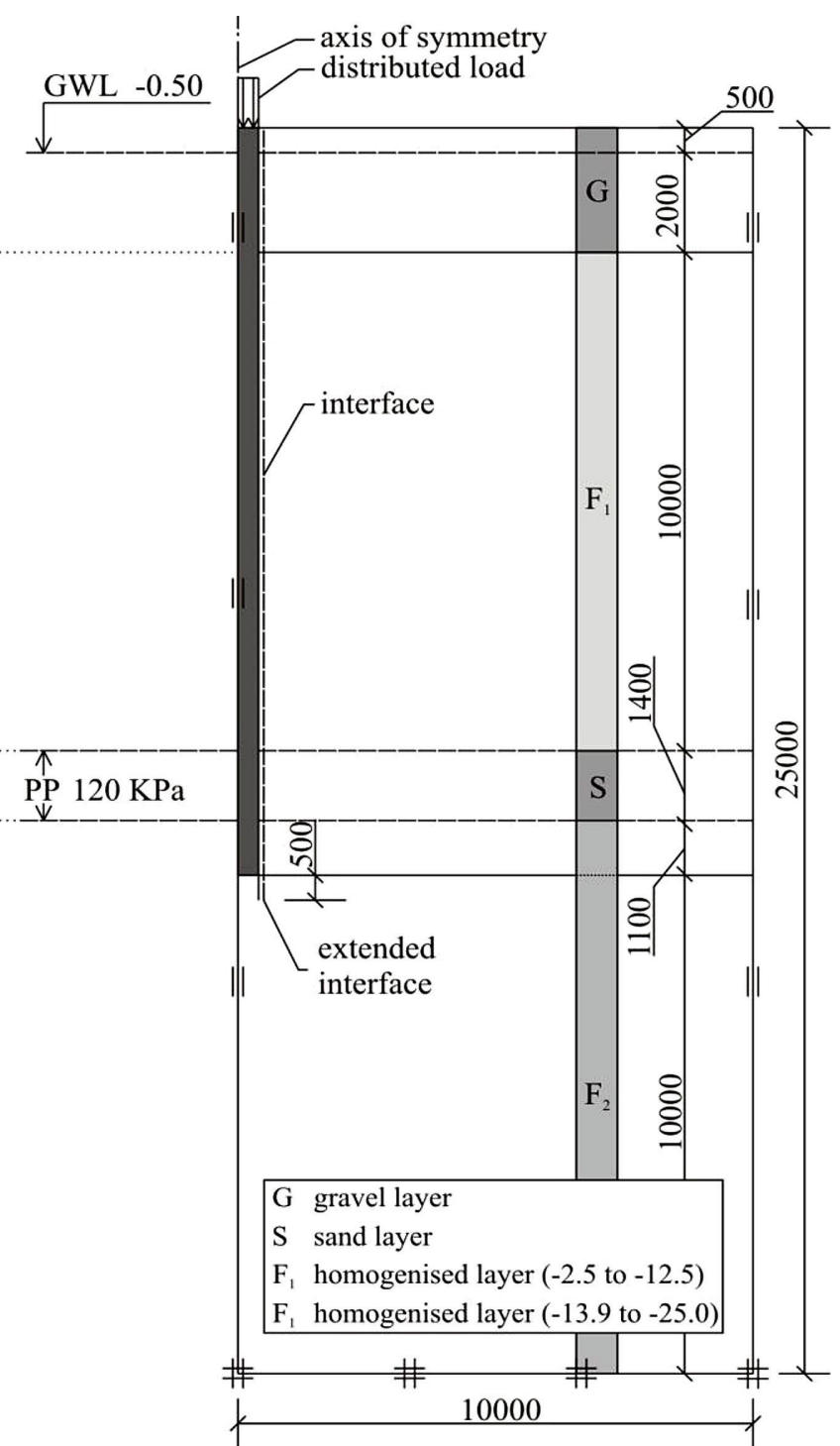

of software is shown in Fig. 2. The geotechnical model respects the upper geological conditions described of the tested area. The basic soil properties input are given in Table 1. The individual properties and values were used according to the requirements of the constitutive models. Detailed descriptions of the model in the Ansys software, as well as in the Plaxis one, are given separately in the following sections.

Tab. 1 Basic soil properties for numerical models.

\begin{tabular}{|c|c|c|c|c|c|}
\hline Name & Gravel well graded & $\begin{array}{c}\text { Silt sandy - Silt } \\
\text { with low plasticity }\end{array}$ & Sand silty & $\begin{array}{c}\text { Silt with low - } \\
\text { intermediate plasticity }\end{array}$ & Pile (Concrete) \\
\hline Symbol & GW & MS - ML & SM & ML - MI & - \\
\hline Altitude (m.a.s.1.) & $126.63-129.13$ & $116.63-126.63$ & $115.23-116.63$ & $<115.23$ & $114.13-129.63$ \\
\hline Depth (m) & 2.5 & 12.5 & 13.9 & 15.0 & 15.0 \\
\hline Thickness (m) & 2.5 & 10.0 & 1.4 & 1.1 & 15.0 \\
\hline$\gamma\left(\mathrm{kN} \cdot \mathrm{m}^{-3}\right)$ & 21 & 19 & 18 & 20 & 24 \\
\hline$\gamma_{\text {sat }}\left(\mathrm{kN} \cdot \mathrm{m}^{-3}\right)$ & 23 & 20 & 21 & 21 & - \\
\hline$\varphi^{\prime}\left({ }^{\circ}\right)$ & 36 & 27.8 & 32.2 & 27.8 & - \\
\hline$c^{\prime}\left(\mathrm{kN} \cdot \mathrm{m}^{-2}\right)$ & 0 & 27.9 & 16.7 & 16 & - \\
\hline$E\left(\mathrm{MN} \cdot \mathrm{m}^{-2}\right)$ & - & - & - & - & 30000 \\
\hline$E_{\text {oed }}^{\text {ref }}\left(\mathrm{MN} \cdot \mathrm{m}^{-2}\right)$ & 133 & 35.2 & 74.3 & 74.5 & - \\
\hline$v(-)$ & 0.2 & 0.38 & 0.3 & 0.4 & 0.1 \\
\hline
\end{tabular}



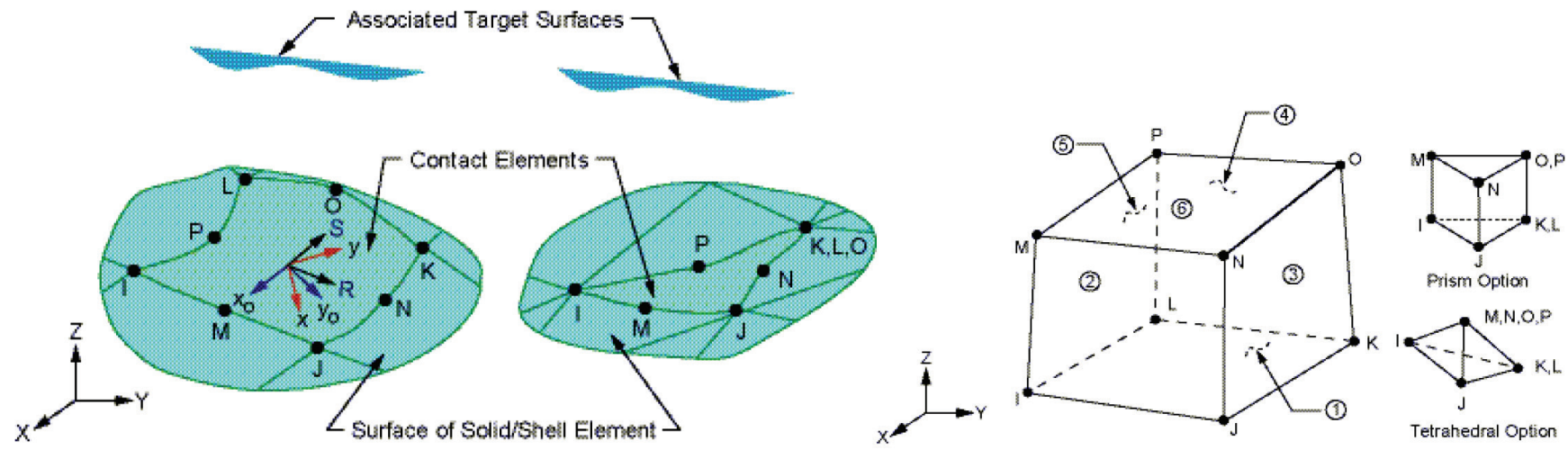

Fig. 3 CONTA174 (left) and SOLID45 (right) elements (ANSYS Release 11, 2007).

\subsection{Numerical simulation of the CFA pile using the Ansys software}

The model consists of a pile (a circular cross section with a diameter of $0.63 \mathrm{~m}$ and a depth of $15 \mathrm{~m}$ ) and a soil model with the dimensions of $20 \mathrm{~m} \times 20 \mathrm{~m} \times 25 \mathrm{~m}$. The soil model is composed of four layers (Fig. 2). To simplify the computational model, only a quarter of the actual model was modelled, and the symmetry of the model was taken into account. The SOLID45, CONTA174 and TARGE170 elements from the ANSYS database (Fig. 3) were used. The SOLID45 element is an 8-node 3D element. The element is defined by eight nodes having three degrees of freedom at each node (translations in the nodal $x, y$, and $z$ directions). This element was used to make a model of the pile and soil. The TARGE170 element was used to represent the 3-D target surfaces. The contact elements themselves overlay the solid elements describing the boundary of the deformable body and are potentially in contact with the target surface defined by this element. This target surface is discredited by a set of target segment elements and is paired with its associated contact surface. The CONTA174 element was used to represent the contact and sliding between the 3-D target surfaces (TARGE170) and the deformable surface defined by this element. These elements were located on the surfaces between the pile and the soil model. An analysis using these elements for spread foundations was published by, e.g., Hruštinec (2013).

The material of the pile model is considered to be reinforced concrete with a Young's modulus of $E=30 \mathrm{GPa}$, a density of $\rho=2400 \mathrm{~kg} . \mathrm{m}^{-3}$, and a Poisson's ratio of $v=0.2$. The material model was created as a multilinear model, as can be seen in the figure below (Fig. 4).

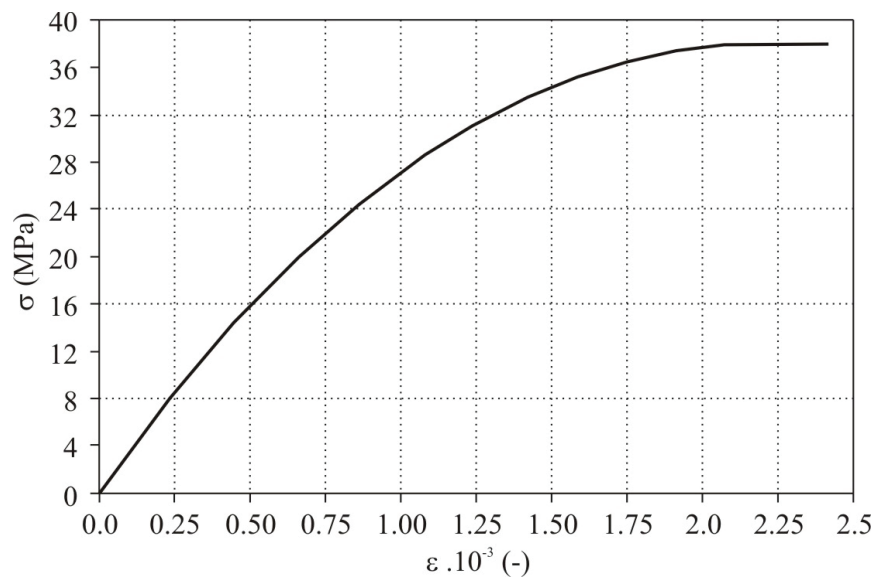

Fig. 4 Multilinear material model of concrete.
The material model of the soil was considered in three ways. Firstly, we considered the material as a linear material model with parameters of $E$ and $v$ for each layer and rigid interface. Secondly, we considered the material as a linear material model with parameters of $E$ and $v$ for each layer again with modelling the interface between the pile and soil. Thirdly, we considered the Drucker - Prager material model with the parameters of Young's modulus $(E)$, Poisson's ratio $(v)$, cohesion $(c)$ and the angle of shear strength $(\varphi)$ for each layer. The Drucker - Prager material model uses the outer cone approximation to the Mohr-Coulomb law (Fig. 5).

For the computational model (see Fig. 6), we applied the following boundary conditions:

1) all the nodes on the lowest area of the soil (with the coordinate $Z=-25 \mathrm{~m}$ ) we considered as rigid (translations in the nodal $x, y$, and $z$ directions are equal to zero).

2) on the lateral areas of the model $(Y=0 \mathrm{~m}, X=0 \mathrm{~m})$ - symmetry was considered,

The load which was applied on the model is composed of a dead load (the gravity accelerate we considered to have a value of 9.8 $\mathrm{m} . \mathrm{s}^{-2}$ ) and a continuous uniform load with a value of $8662 \mathrm{kN} \cdot \mathrm{m}^{-2}$ (concentrated force of $2700 \mathrm{kN}$ impacted on the circle area with a diameter of $0.63 \mathrm{~m}$ ) applied on the top area of the pile.

\subsection{Numerical simulation of a CFA pile using the Plaxis software}

The Plaxis 2011 2D commercial software was used for the numerical analyses. The software permits the use of advanced constitutive models. The Hardening Soil (HS) model was used in our

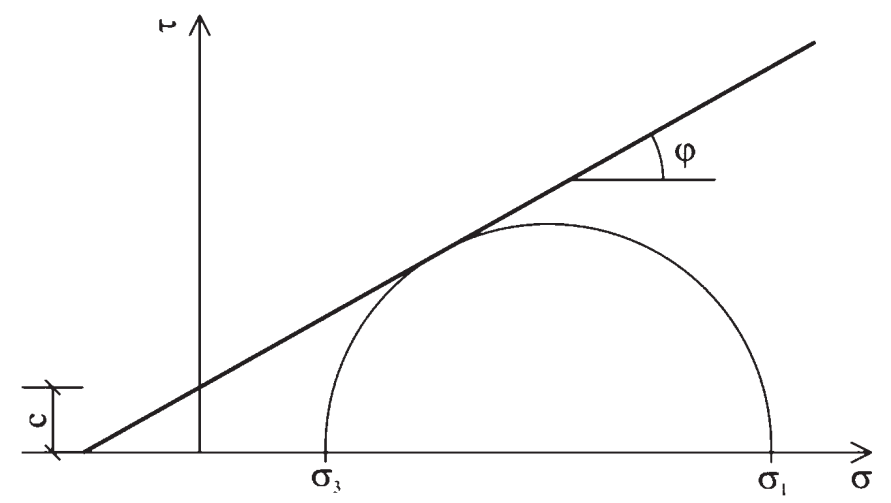

Fig. 5 Mohr-Coulomb failure envelope. 


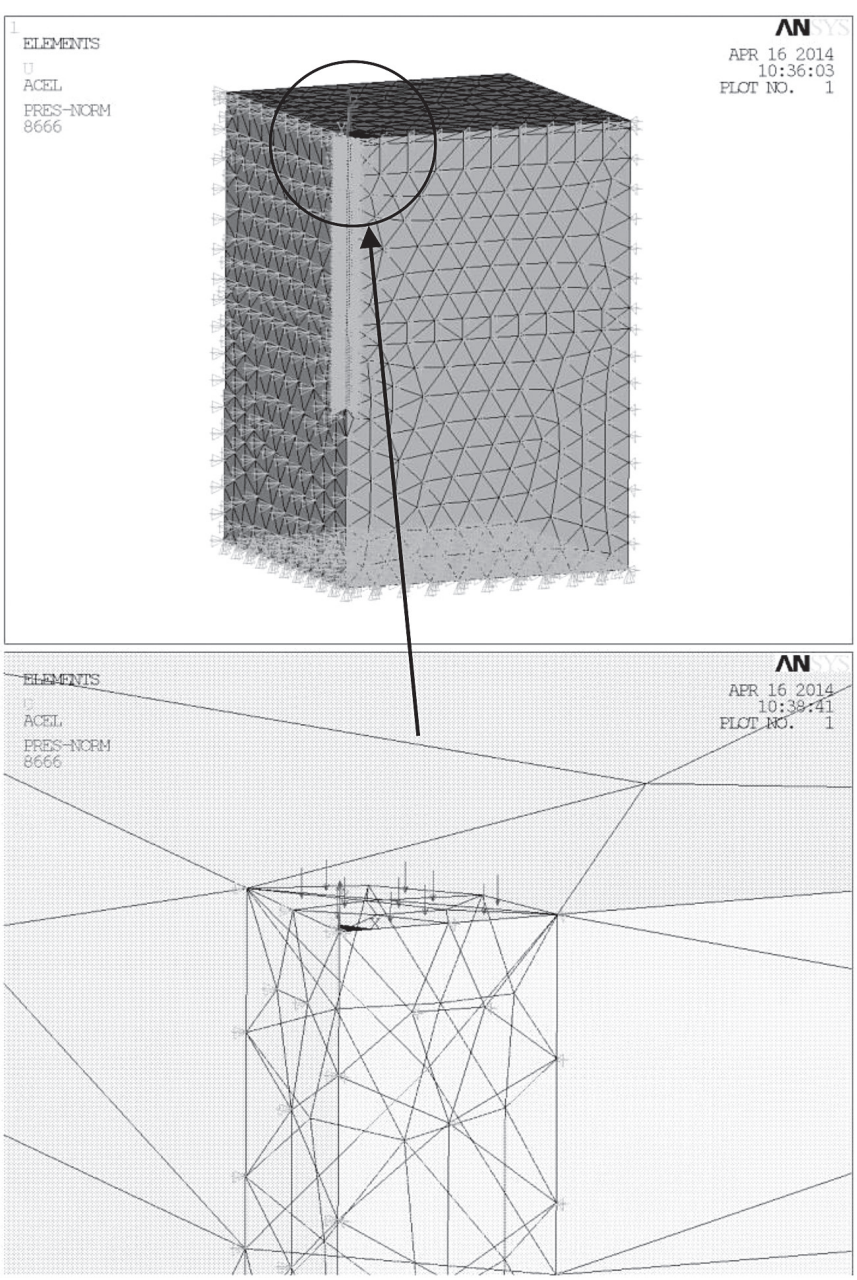

Fig. 6 FEM model (Ansys, 3D).

analyses for soil layers. The model presents a further qualitative shift in the description of a more realistic behaviour of soil, including soft soil and stiff soil (Shanz et al., 1999), as opposed to linear elastic, nonlinear elastic and linear elastic - perfectly plastic constitutive models.

The HS model considers the hyperbolic relationship between the vertical stress and the deviatoric stress in primary triaxial loading. When subjected to primary deviatoric loading, the soil shows a decreasing stiffness; simultaneously, an irreversible plastic strain develops (Shanz et al., 1999). In contrast to elastic, perfectly plastic models, the yielding surface of the HS model is not fixed in a principal stress space, but expands due to the plastic straining. A distinction can be made between the two main types of hardening: shear and compression hardening (Plaxis - Material Models Manual, 2011). The stress-strain relationship of the MC and HS models is compared in Fig. 7.

The basic characteristics of the HS model are:

- Stress-dependent stiffness according to a power low $-m$,

- Plastic straining due to a primary deviatoric loading $-E_{50}$ ref,

- Plastic straining due to a primary compression $-E_{\text {oed }}$ ref,

- Elastic unloading $-E_{\text {ur }}^{\text {ref }}, v_{\text {ur }}$,

- The Mohr-Coulomb failure criterion $-c^{\prime}, \varphi^{\prime}, \psi^{\prime}$.

The interface elements used in Plaxis are generally modelled by means of a bilinear MC model. The reduction of the soil properties is defined by the parameter $R_{\text {inter }}$, which is given by the ratio of the strength of the soil and the strength in the interface. The Hardening Soil model with small strain stiffness (the HSs model) is a modification
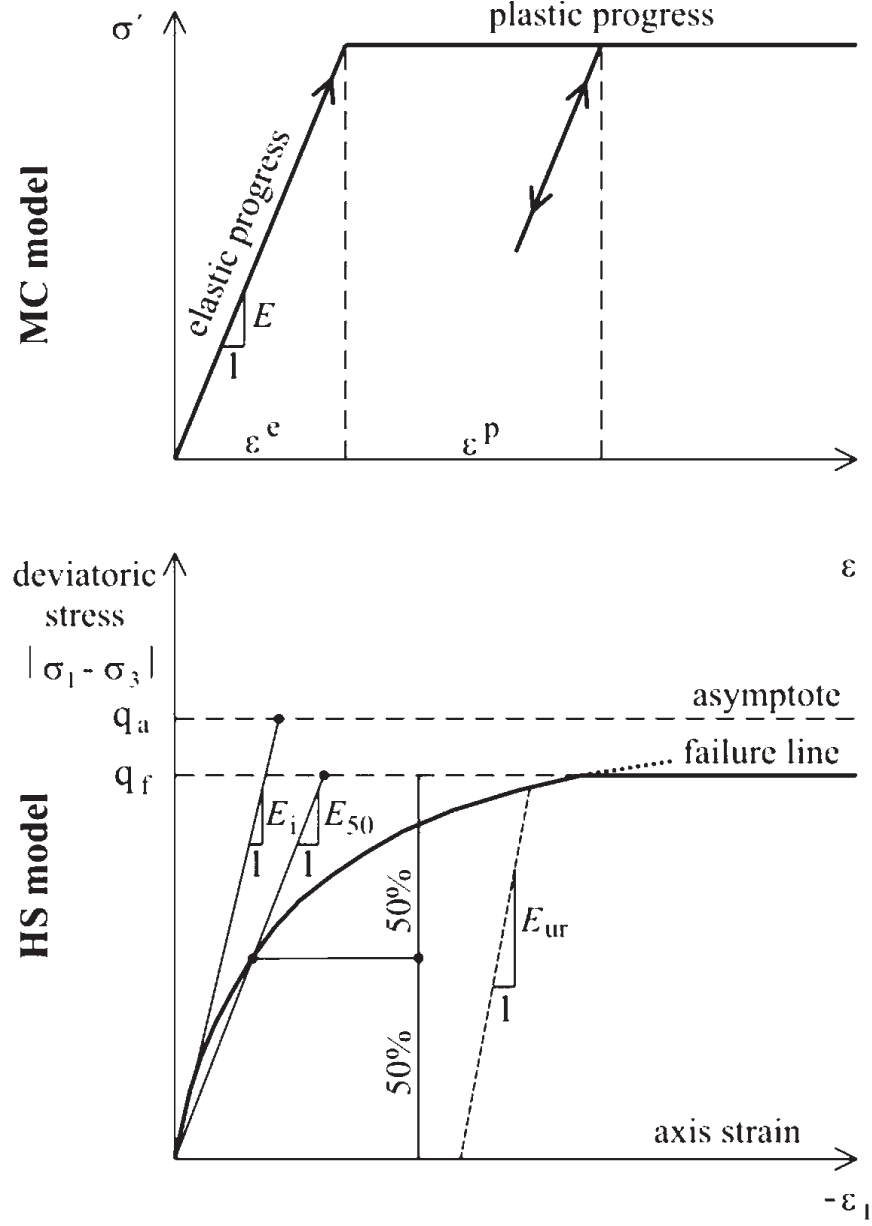

Fig. 7 Basic comparison of $M C$ (up) and HS material model (down) (Plaxis-Material Models Manual, 2011).

of the HS model for the increased stiffness of soil with small strains. The impact of the input parameters of both the HS and HSs models were analysed by Miča et al. (2011).

The model for the analysis of the CFA pile was created to be axisymmetric with the use of 15-node triangular elements in all the clusters. The pile was modelled using the LE material model, and the soil layers were modelled with the advanced HS model described. The pile body was modelled as a cluster with the dimensions of the radius and pile length. The boundaries of the model are $20 \mathrm{~m}$ in a horizontal and $25 \mathrm{~m}$ in a vertical direction. A distributed load of 8662 $\mathrm{kPa}$ was placed on top of the pile. The extended interface below the pile's base was modelled according to the recommendations of the Plaxis manual (Shanz et al., 1999). The first construction stage represents the initial geological conditions. The horizontal stresses are based on Jaky's law. The second stage is the creation of the pile. The simulation of the static load test (loading and unloading steps) was defined one month after the second stage.

\section{RESULTS OF THE NUMERICAL ANALYSIS}

The numerical analysis of the CFA pile was prepared in the form of a parametric study. The objective of the parametric study was to compare different ways of modelling the interface between the pile and soil layers. The study also includes a comparison of the different constitutive material models for soil as well as the modelling of the groundwater and the overconsolidation of the fine-grained soil. In the first step, the numerical analysis was done independently using both 
programs. The results of the numerical modelling were compared with the results of the static load test of the pile in all the cases. In the second step, the main differences of the programs used were analysed.

\subsection{Ansys}

The results of the numerical analysis, which was executed using Ansys software, are presented in Table 2 and Graphs 1- 3. The parametric study is divided into three parts.

In the first part (Graph 1 - curves A1-A4), a linear-elastic material model without the modelling of the interface $(N)$ between the pile and the soil is considered. The different values of the elastic modulus $\left(1^{*} E, 0.85^{*} E, 0.75^{*} E\right.$ and $\left.0.5^{*} E\right)$ are compared with the measured load-settlement curve of the pile.

A linear-elastic model with the modelling of interface $(Y)$ between the pile and soil is shown in Graph 2 (curves A5 - A6). The coefficient of the friction between the pile's body and the soil was selected as a value of 0.7 . The soil properties were similar as in the first cases.

In the third part (Graph 3 - curves A9 - A12), the Drucker-Prager material model was used for modelling the soil layers. As can be seen, the most appropriate results (in comparison with the static load test) are obtained in cases when $E=1^{*} E$ for the elastic part of the loadsettlement curve. In the plastic part, when the full mobilisation of the shaft friction is achieved, it is recommended to reduce the elastic modulus according to our analyses (up to $0.5^{*} E$ for the pile-bearing capacity).

Tab. 2 Results of numerical analysis of CFA pile by the Ansys software.

\begin{tabular}{|c|c|c|c|c|c|}
\hline \multirow{2}{*}{ Mark } & \multirow{2}{*}{ Interface } & \multirow{2}{*}{$E_{\text {reduction }}$} & $\begin{array}{c}\text { Settlement } \\
(\mathrm{mm})\end{array}$ & & \multicolumn{2}{|c|}{ Resistance } \\
\cline { 5 - 6 } & & & 9.46 & 560 & Shaft $(\mathrm{kN})$ \\
\hline SLT & & & 5.740 \\
\hline $\mathrm{A} 1$ & $\mathrm{~N}$ & 1.0 & 5.77 & 185 & 2515 \\
\hline $\mathrm{A} 2$ & $\mathrm{~N}$ & 0.85 & 6.42 & 206 & 2494 \\
\hline $\mathrm{A} 3$ & $\mathrm{~N}$ & 0.70 & 7.32 & 235 & 2465 \\
\hline $\mathrm{A} 4$ & $\mathrm{~N}$ & 0.50 & 9.31 & 298 & 2402 \\
\hline $\mathrm{A} 5$ & $\mathrm{Y}$ & 1.0 & 7.25 & 232 & 2468 \\
\hline $\mathrm{A} 6$ & $\mathrm{Y}$ & 0.85 & 7.98 & 256 & 2444 \\
\hline $\mathrm{A} 7$ & $\mathrm{Y}$ & 0.70 & 9.01 & 289 & 2411 \\
\hline $\mathrm{A} 8$ & $\mathrm{Y}$ & 0.50 & 11.31 & 363 & 2337 \\
\hline $\mathrm{A} 9$ & $\mathrm{~N}$ & 1.0 & 6.11 & 196 & 2504 \\
\hline A10 & $\mathrm{N}$ & 0.85 & 7.07 & 227 & 2473 \\
\hline A11 & $\mathrm{N}$ & 0.70 & 8.48 & 272 & 2428 \\
\hline A12 & $\mathrm{N}$ & 0.50 & 10.06 & 323 & 2377 \\
\hline
\end{tabular}

Interface $\mathrm{Y}$ - Interface between the pile and soil is modelled Interface $\mathrm{N}$ - Interface between the pile and soil is not modelled

\subsection{Plaxis}

The results of the numerical analysis executed using the Plaxis software are presented in Table 3 and Graphs 4 - 5. The study includes the results of eight models marked as P1 - P8. The study especially focuses on the impact of the value of the $R_{\text {interface }}$ and also the modelling of the groundwater and the impact of the overconsolidation (OCR). The values of the $R_{\text {interface }}$ were selected in a range of 0.85 to 1.00 according to the previous studies (Stacho, 2013; Stacho, 2014).

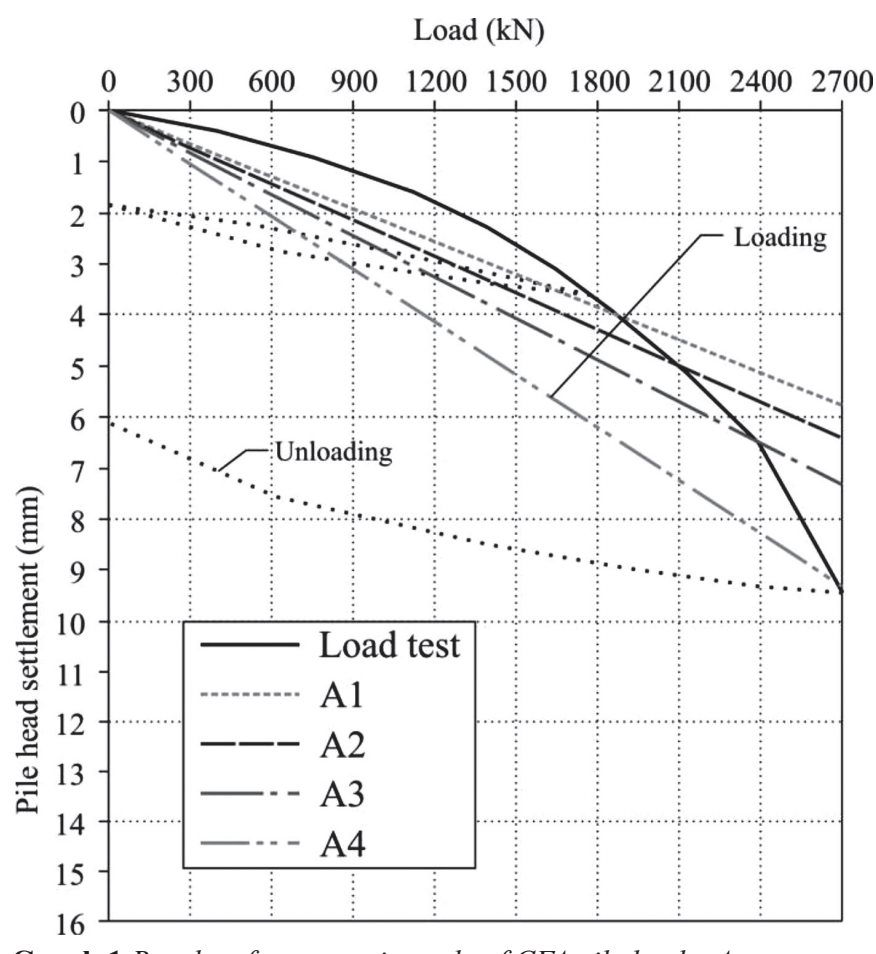

Graph 1 Results of parametric study of CFA pile by the Ansys software (models A1 - A4).

Load $(\mathrm{kN})$

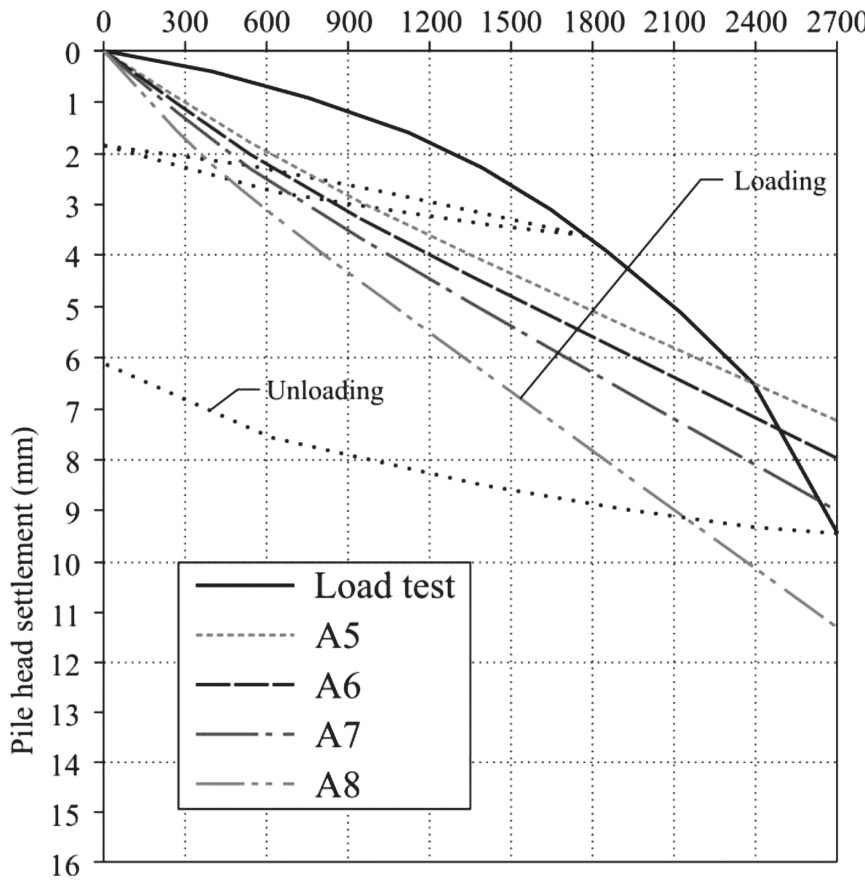

Graph 2 Results of parametric study of CFA pile by the Ansys software (models A5 - A8).

In the P1 and P2 models (Graph 4), the groundwater level was modelled $0.5 \mathrm{~m}$ below the surface using a generated phreatic level, and it was considered over the full depth of the profile (model). This assumption of the impact of the groundwater was also used in the original design of the CFA pile by using an analytical calculation model (Pochman, Šimek, 1989), which is often used for the design of pile foundations in Slovakia and the Czech Republic. The $R_{\text {interface }}$ was considered to be 0.95 and 1.00. A comparison of the PA and P2 
Load $(\mathrm{kN})$

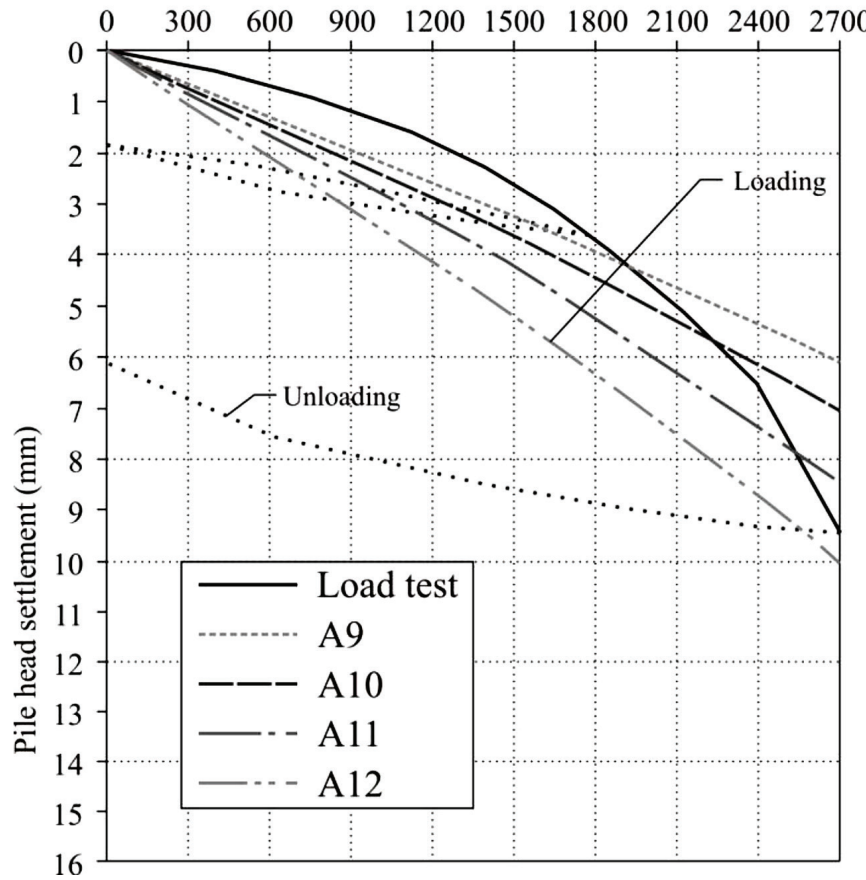

Graph 3 Results of parametric study of CFA pile by the Ansys software (models A9-A12).

models with the results of the SLT shows that the load-settlement curves calculated significantly underestimate the measured loadsettlement curve of the pile. For the P3 - P5 models (Graph 4), the values of the $R_{\text {interface }}$ were selected as $0.85,0.90$ and 0.95 . The groundwater was modelled according to the actual assumptions with respect to the engineering-geological conditions of the tested area. The free phreatic level was only modelled in the upper quaternary gravel (G). The groundwater in the lower soil layers was modelled using user-defined pore pressures (PP). That was especially necessary for the sandy layer (S), where the pore pressure achieved $120 \mathrm{kPa}$. The most appropriate result in comparison with the SLT was obtained in the case of $\mathrm{P} 4$, where the $R_{\text {interface }}$ is equal to 0.90 .

The overconsolidation ratio (OCR) of the fine-grained soils has not been measured in any nearby area yet. The pre-overburned pressure (POP) was selected at a value of $120 \mathrm{kPa}$, based on previous analyses as well as discussions with engineering geologists. The results of the P6 and P8 models, which include the POP, are presented in Graph 5 . The use of POP led to very accurate results of the modelling of
Load $(\mathrm{kN})$

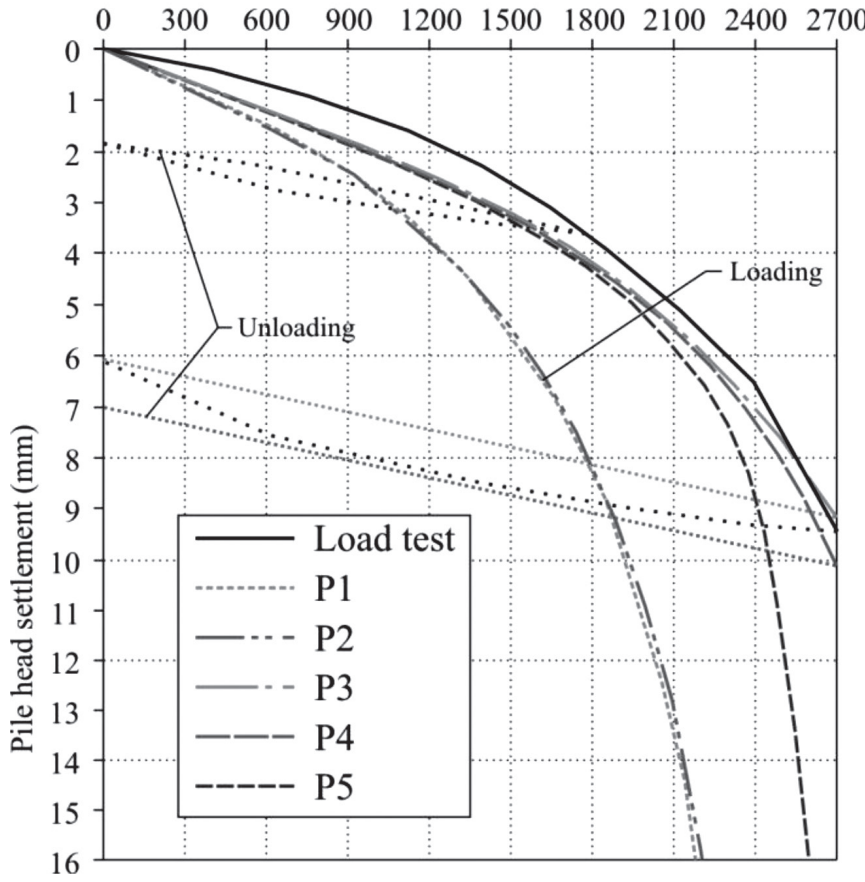

Graph 4 Results of parametric study of CFA pile by the Plaxis software (models P1-P5).

the tested CFA pile. The most appropriate result was obtained in the case of the P7 model (see Tab. 3 and Graph 5). In Figs. 8 and 9, the vertical deformations and vertical stresses are shown below the pile base under a load of $2700 \mathrm{kN}$ from the Plaxis software.

The proportion of the pile base and shaft of the total pile's resistance is an important part of the analyses. It shows the magnitude of the load transferred by the pile base, which is transferred by shaft friction. This analysis is shown in Graph 6, which compares the results of the calculated load-settlement curves and base resistances with the results of the static load test. The results of the calculations using Plaxis are the same as in the P7 case. The results of the calculations using Ansys were obtained by constantly decreasing the elastic modulus while increasing the load from the A9 - A12 cases. Through use of the Plaxis software, it was possible to calculate more reliable results; however, calculations using Ansys allow for the obtaining of approximate results. The calculated and measured decrease of the load over the pile's length (with the depth) is compared in Graph 7.

Tab. 3 Results of numerical analysis using the Plaxis software.

\begin{tabular}{|c|c|c|c|c|c|c|c|}
\hline \multirow{2}{*}{ Mark } & \multirow{2}{*}{$R_{\text {interface }}$} & \multirow{2}{*}{ Water } & \multirow{2}{*}{ POP $(\mathrm{kPa})$} & \multirow{2}{*}{$\begin{array}{l}\text { Settlement } \\
(\mathrm{mm})\end{array}$} & \multirow{2}{*}{$\begin{array}{l}\text { Unloading } \\
(\mathrm{mm})\end{array}$} & \multicolumn{2}{|c|}{ Resistance } \\
\hline & & & & & & Base $(\mathrm{kN})$ & Shaft $(\mathrm{kN})$ \\
\hline SLT & & & & 9.46 & 6.11 & 560 & 2140 \\
\hline $\mathrm{P} 1$ & 0.95 & $\mathrm{GWL}^{1}$ & - & 48.30 & 43.30 & 689 & 2011 \\
\hline $\mathrm{P} 2$ & 1.00 & $\mathrm{GWL}^{1}$ & - & 47.20 & 42.20 & 694 & 2006 \\
\hline P3 & 0.85 & $\mathrm{GWL}^{2}+\mathrm{PP}$ & - & 21.00 & 16.70 & 765 & 1935 \\
\hline $\mathrm{P} 4$ & 0.90 & $\mathrm{GWL}^{2}+\mathrm{PP}$ & - & 10.30 & 6.08 & 474 & 2226 \\
\hline P5 & 0.95 & $\mathrm{GWL}^{2}+\mathrm{PP}$ & - & 9.27 & 6.13 & 440 & 2260 \\
\hline P6 & 0.85 & $\mathrm{GWL}^{2}+\mathrm{PP}$ & 120 & 18.40 & 15.10 & 772 & 1928 \\
\hline P7 & 0.90 & $\mathrm{GWL}^{2}+\mathrm{PP}$ & 120 & 9.35 & 5.70 & 490 & 2210 \\
\hline P8 & 0.95 & $\mathrm{GWL}^{2}+\mathrm{PP}$ & 120 & 8.28 & 5.13 & 463 & 2237 \\
\hline
\end{tabular}

$\mathrm{GWL}^{1}$ - Groundwater is modelled in full profile

$\mathrm{GWL}^{2}+\mathrm{PP}-$ Groundwater is modelled only in gravel layer and pore pressure in sandy layer

POP - Pre-over burned pressure 


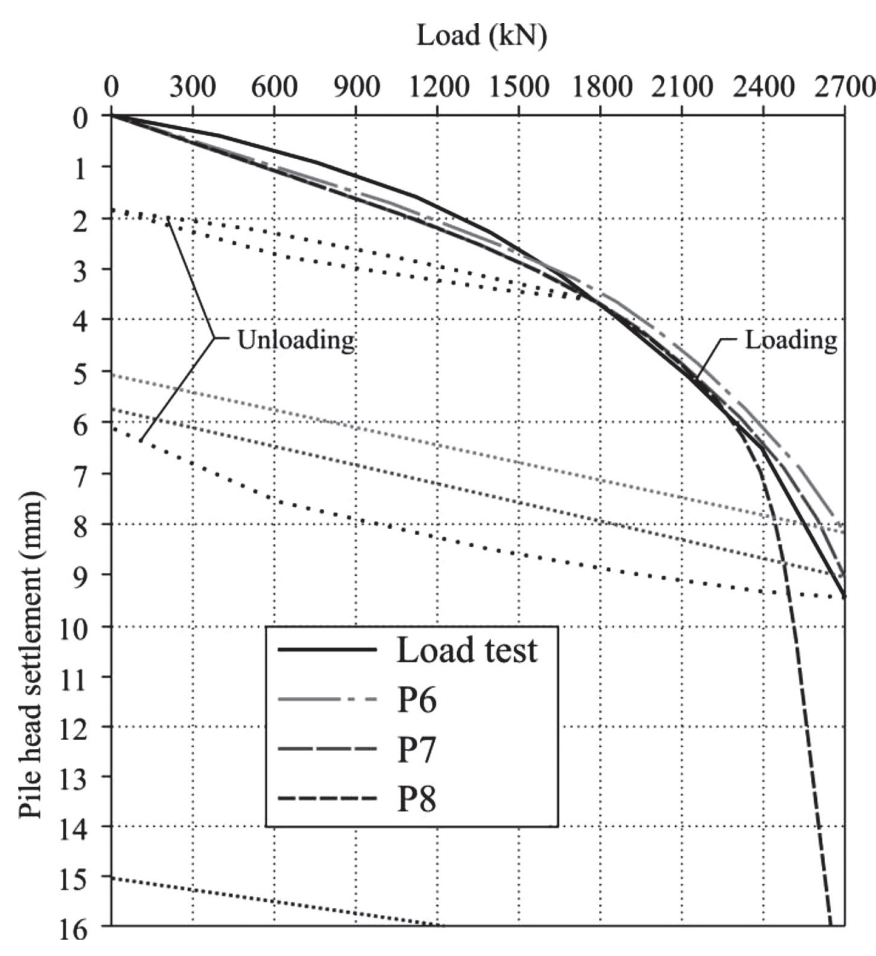

Graph 5 Results of parametric study of CFA pile by the Plaxis software (models P6-P8).

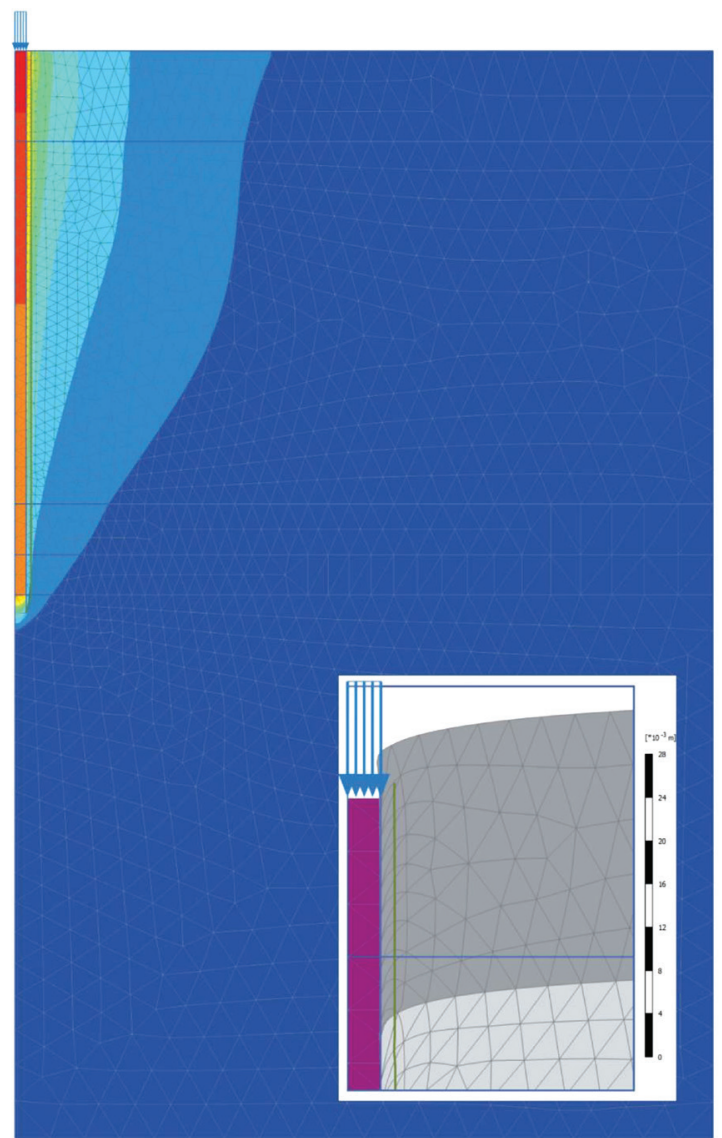

Fig. 8 Vertical displacements under a $2700 \mathrm{kN}$ load (in the Plaxis software).

\section{CONCLUSION}

Traditional bored piles and CFA piles are the most used technologies for pile foundations in Slovakia. The CFA technology is a quiet, fast and very economical piling technology. In suitable geological conditions, CFA piles are an attractive alternative to traditional bored piles. Suitable geological conditions for CFA piles especially include clays of a medium-to-firm consistency, efflorescent sandstones and limestones, and fine coarse-grained soils. The design of CFA piles in Slovakia still presents some unanswered questions.

The paper deals with numerical analyses of static load tests of CFA piles. The numerical analyses were prepared in the form of parametric studies using two types of software, i.e., Plaxis and Ansys, based on FEM. The Plaxis software is a specialised software for geotechnical constructions and allows the use of advanced constitutive material models of soil and more sophisticated modelling of, e.g., the impact of groundwater, overconsolidation, unloading and reloading. In comparison, the Ansys software permits ordinary modelling of large structure systems together with their foundations.

Numerical analyses of static load tests of CFA piles include a comparison of load-settlement curves and distributions of the load over the pile's length. The results of the study show that both types of software can be used for pile design in their own forms and with sufficient accuracy. The Plaxis software allows for more correct modelling of soil behaviour, which leads to more suitable results in comparison with the Ansys software. The most suitable results were obtained with the P7 model, where the influence of the groundwater was modelled by user-defined pore pressures; the overconsolidation of fine-grained soils was taken into account; and the interface between the pile and soil layers was modelled using the $R_{\text {interface }}$ of a value of 0.9 . The study also shows that correct modelling of pile foundations for large structures with the Ansys software leads to approximate results.

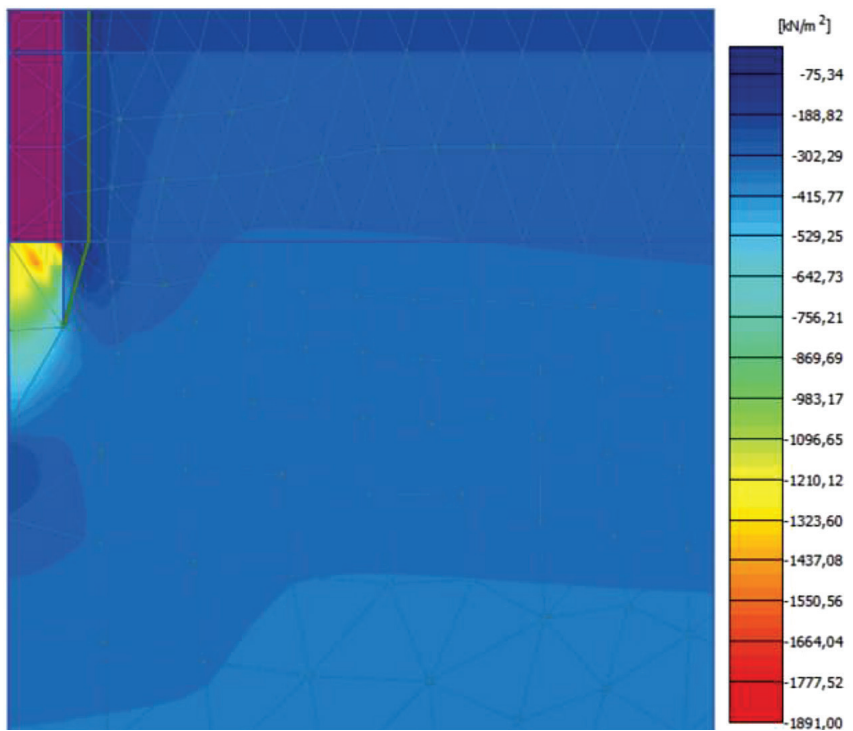

Fig. 9 Vertical stresses under a $2700 \mathrm{kN}$ load (in the Plaxis software). 


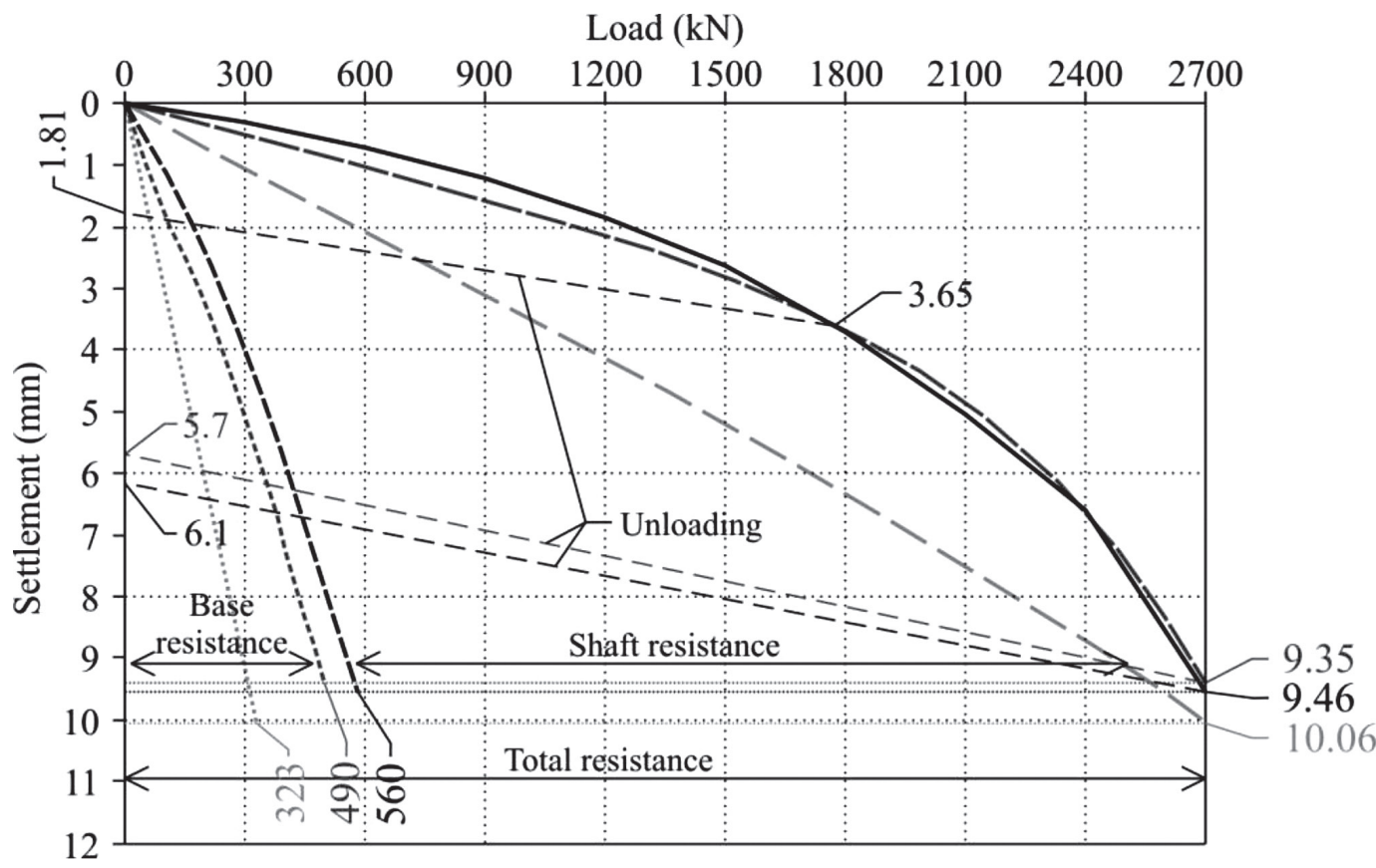

Static load test

Total resistance

Base resistance

FEM (Plaxis)

- - Total resistance

Base resistance

FEM (Ansys)

- - - Total resistance

Base resistance

Graph 6 Comparison of results of static load test with the most appropriate results of numerical analysis (Plaxis software - model P7 and Ansys software - model A12).

Load $(\mathrm{kN})$

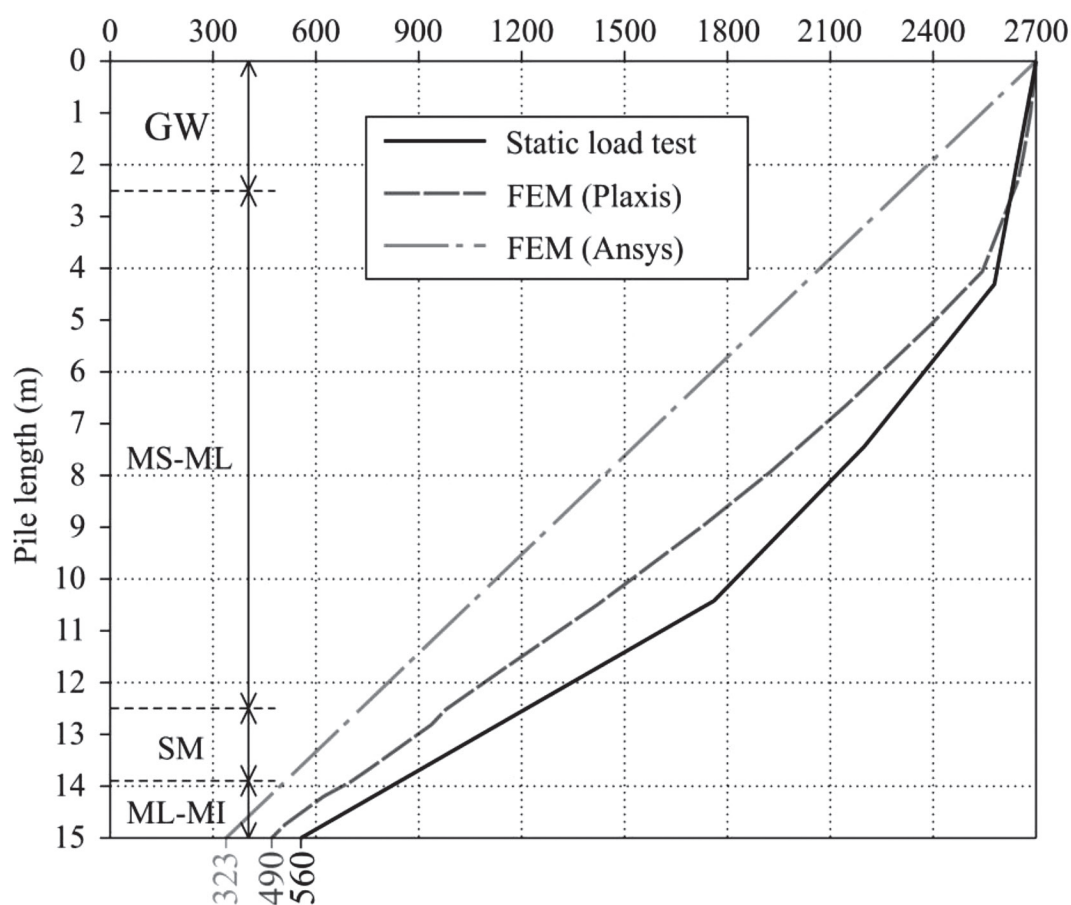

Unit shaft friction $(\mathrm{kPa})$

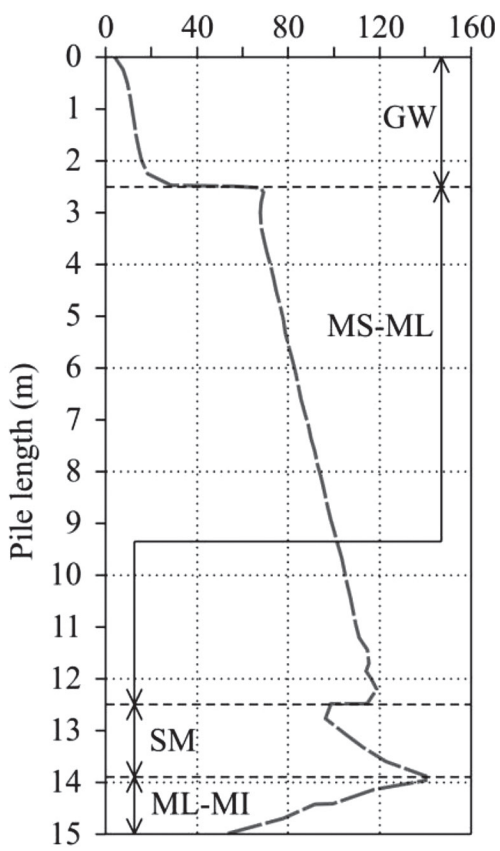

Graph 7 Comparison of calculated and measured decrease of load over the pile length (models: Plaxis P7, Ansys A12).

\section{Acknowledgements}

The paper is one of the outcomes of Grant VEGA agency No. 1/0241/13, STU Grant for support of young researchers - Optimal Design of Constructions Considering Non-linear Physical Properties of Materials (in Slovak: Optimálny návrh konštrukcií s uvážením nelineárnych fyzikálnych vlastností materiálov), STU Grant for support of young researchers - New Methods for the Design of Drilled Displacement System Piles in Slovakia. (In Slovak: Nové metódy pre navrhovanie vŕtaných roztláčaných pilot na Slovensku). 


\section{REFERENCES}

ANSYS Release 11 (2007) Documentation Preview.

Almeida, V. S. - De Paiva, J. B. (2007) Static analysis of soil/pile interaction in layered soil by BEM/BEM coupling. Advances in Engineering Software. No. 38, pp. 835-845.

Brown, D. A. (2005) Practical consideration in the selection and use of continuous flight auger and drilled displacement piles. Advances in design and testing deep foundations, Texas, U.S., pp. 251-261.

Coyle, H. M. - Reese, L. C. (1966) Load transfer for axially loaded piles in clay. Soil Mechanics and Foundations 1966, No. 92, pp. 1-26.

Cummins, D. (2007) Comparison of performance of CFA piles in weak rock with Eurocode design predictions. Presentations from $18^{\text {th }}$ European Young Geotechnical Engineers Conference held in Ancona, Italy.

Dijkstra, J. - Broere, W. - Heeres, O. M. (2011) Numerical simulation of pile installation. Computers and geotechnics, No. 38 , pp. 612-622.

Feda, J. (1977) Interaction between pile and ground. Prague, Academia, 156 pp. [in Czech]

Fleming, K. - Weltman, A. - Randolph, M. - Elson, K. (2008) Piling Engineering - Third Edition. Taylor \& Francis e-Library, 398 pp., ISBN 0-203-937654-3

Gavin, K. G. - Cadogan, D. - Casey, P. (2009) Shaft Capacity of Continuous Flight Auger Piles in Sand. American Society of Civil Engineers, pp. 780-798, ISSN 1943-5606

Hruštinec, L. (2014) Numerical analysis of the interaction between shallow (square, circular, strip) foundations and subsoil. Journal of civil engineering and architecture. Vol. 7, No. 7, pp. 875-886, ISSN 1934-7359

Husár, R. (2008) Ground investigation for Centrál building, Terratest Bratislava, 29 pp. [in Slovak].

Kim, Y. - Jeong, S. (2011) Analysis of soil resistance on laterally loaded piles based on $3 D$ soil-pile interaction. Computers and geotechnics. No. 38, pp. 248-257.

Mandolini, A. - Romandini, M. - Russo, G. - Viggiani, C. (2002) Full Scale Loading Tests on Instrumented CFA Piles. Deep Foundations 2002, American Society of Civil Engineers, pp. 10881097, ISBN: 978-0-7844-0601-4

Masopust, J. (1994) Bored Piles. Prague, Čenek a Ježeks.r.o., 263 pp. [in Czech].

Miča, L. - Chalmovský, J. - Fiala, R. - Račanský, V. (2011) $N u$ merical analysis of retaining structures. CERN academic publishing, Brno, 143 pp. ISBN 978-80-7204-773-4 [in Czech]

Mohamedzein, Y.E.A. - Mohamed, M.G. - El Sharief, A.M. (1999) Finite element analysis of short piles in expansive soils. Computers and Geotechnics, Vol. 24 / No. 3, pp. 231-243, ISSN: 0266-352X

Nejad, F. P. - Jaksa, M. B. - Kakhi, M. - McCabe, B. A. (2009) Prediction of pile settlement using artificial neutral networks based on standard penetration test data. Computers and geotechnics, No. 36, pp. $1125-1133$.
NeSmith, W. (2002) Static Capacity Analysis of Augered, Pressure-Injected Displacement Piles. Deep Foundations 2002, U.S., pp. 1174-1186.

Plaxis (2011) Material Models Manual 202 pp. Available at: http:// www.plaxis.nl/files/files/2D2011-3-Material-Models.pdf, (accessed at 08/05/2014).

Pochman, R. - Šimek, J. (1989) Pile foundations. Commentary to ČSN 73 1002. FÚNM, Prague, 75 pp., ISBN 80-85 111-04-7 [in Czech]

Pokorný, M. - Šujan, M. (2004) Lakeside Office Park Bratislava, Preliminary ground investigation - Ground investigation report. EQUIS Bratislava, 42 pp. [in Slovak].

Pucker, T. - Grabe, J. (2012) Numerical simulation of the installation process of full displacement piles. Computers and geotechnics, No. 45, pp. 93-106.

Said, I. - De Gennaro, V. - Frank, R. (2009) Axisymmetric finite element analysis of pile loading tests. Computers and Geotechnics, No. 36, pp. 6-19.

Shanz, T. - Vermeer, P. A. - Bonnier, P. G. (1999) The Hardening Soil model: Foundation and verification. Beyond 2000 in computational geotechnics - 10 Years of Plaxis. Balkema, Rotterdam, ISBN 90-5809-040-X

Sheng, D. - Eigenbrod, K. D. - Wriggers, P. (2005) Finite element analysis of pile installation using large-slip fictional contact. Computers and geotechnics, No. 32, pp. 17-26.

Stacho, J. (2013) Alternative calculation method for the design of CFA piles. Juniorstav 2013 (CD-ROM): $15^{\text {th }}$ International conference of PhD students.VUT, Brno, Brno University of Technology, 8 pp., ISBN 978-80-214-4670-0 [in Slovak]

Stacho, J. (2014) Determination of CFA and DDS pile resistance by using FEM. Juniorstav 2014 (CD-ROM): 16 ${ }^{\text {th }}$ International conference of PhD students.VUT, Brno, Brno University of Technology, 8 pp., ISBN 978-80-214-4670-0 [in Slovak]

Tomlinson, M. - Woodward, J. (2007) Pile design and construction practise - Fifth edition. Taylor \& Francis e-Library, 551 pp., ISBN 0-203-96429-2

Viggiani, C. - Mandolini, A. - Russo, G. (2012) Piles and Pile Foundations. Taylor \& Francis, U.K., 278 pp., ISBN 978-0-41549066-5

Wakai, A. - Gose, S. - Ugai, K. (1999) 3D elasto-plastic finite element analyses of pile foundations subjected to lateral loading. Soils and Foundations, Vol. 39, pp. 97-111, ISSN 134-7452

Wang, Z. - Xie, X. - Wang, J. (2012) A new nonlinear method for vertical settlement prediction of a single pile and pile groups in layered soils. Computers and geotechnics, No. 45, pp. 118-126.

Wehnert, M. - Vermeer, P. A. (2004) Numerical analyses of load tests on bored piles. Numerical models in geomechanics, Proceedings of the 9th Symposium on Numerical Models in Geotechnics, Ottawa, Canada, pp. 505-516, ISBN 9789058096364 